EIJEST

\title{
A STUDY OF UNSTEADY FLOW THROUGH EARTH DAMS*
}

\author{
Magdy H. Mowafy, Mohamed N. Salem, Eman A. El-nikhily, Yasser E. Shaaban ${ }^{+}$ \\ Water Eng. Dept., Zagazig University, Zagazig, Egypt.
}

\begin{abstract}
Z_SOIL, commercial software based on finite element technique is proposed to simulate the unsteady seepage flow through earth dams, with variable upstream water heads. Experimental work, using Permeability and seepage model is conducted to verify the reliability and the accuracy of the numerical model. The accuracy and reliability of the model are adequate to handle unsteady flow problems with complex conditions. It is also demonstrated that the method of determining the seepage surface through the saturation described is natural, logical and practical in actual applications. The method provides a relatively simple computing scheme, as compared with traditional methods.
\end{abstract}

KEY WORDS: Numerical Analysis; Unsteady Seepage; Earth Dam; Finite Element Method.

\section{UNE ÉTUDE DE ÉCOULEMENT INSTABLE PAR TERRE DAMS}

\section{RÉSUMÉ}

Logiciel commercial Z_SOIL basé sur la technique des éléments finis est proposé de simuler l'écoulement des eaux d'infiltration instable par des barrages de terre, avec des variables chefs d'eau en amont. Les travaux expérimentaux, utilisant la perméabilité et infiltration modèle est effectuée pour vérifier la fiabilité et la précision du modèle numérique. La précision et la fiabilité du modèle sont suffisantes pour traiter les problèmes d'écoulement instables d'infiltration avec des conditions complexes. Il est également démontré que le procédé de détermination de la surface d'absorption à travers la description de saturation est naturel, logique et pratique dans des applications réelles. Le procédé fournit un schéma de calcul relativement simple, en comparaison avec les méthodes traditionnelles.

MOTS CLÉS: Analyse Numérique; Infiltration Instable; Barrage Terre; Méthode Des Eléments Finis.

\footnotetext{
* Received: 27/10/2013, accepted: 1/12/2013, Ref. No. 167, (original paper)

+ Contact author(dhaheer_abdelsamad@yahoo.com)
} 


\section{A STUDY OF UNSTEADY FLOW THROUGH EARTH DAMS}

Mowafy, Salem, El-nikhily, Shaaban

\section{INTRODUCTION}

The seepage flow through an embankment with unsteady boundary conditions is of interest in many hydrological and environmental problems, such as the stability of earth dams or slopes with unsteady water level boundary conditions in civil engineering. The interaction of surface water with groundwater in water resources scenarios, the pollution in groundwater and its pervasion in environment, the infiltration of rainfall, the petroleum exploitation and the seawater intrusion due to tidal fluctuations in a coastal aquifer[1-4].

The seepage flow with free surface is of great concern in the past few years [5-7]. Recently, Ge et al., [8] presented an elementfree method for unsteady seepage with free surface, with related algorithms for seepage analysis. Chen et al., [9] put forward a Variable Element Seepage Coefficient Method for seepage numerical analysis with free surface, but it requires a significant modification of the hydraulic conductivity in unsaturated region. Zhang et al., [10] successfully applied the improved cut-off negative pressure method to simulate the unsteady seepage flow with free surface. Hua et al., [11] applied element-free Gakerkin method in a numerical simulation of the dynamic response of poroelastic seabed under wave action with enhanced performance. Sun et al., [12,13]studied the unsteady seepage affected by rainfall infiltration and water level fluctuation with a saturated-unsaturated seepage model based on water-air two-phase flow theory, and obtained some interesting results. Lockington [14] presented a weighted residual method solving the one-dimensional Bouss-inesq equation for both the recharging and the dewatering of a homogeneous, unconfined aquifer. Ataie-Ashtiania et al., [15] modified SUTRA method in order to simulate the unsteady seepage flow in unconfined aquifers affected by a periodic boundary condition. Ross [16] developed a fast method to solve the Richards's equation for water transport, to be used in problems of rainfall, surface evaporation and drainage. Varado et al., [17] further studied the numerical scheme proposed by Ross, and it is shown that the

model can provide robust and accurate solutions, but a finer discretization than that proposed by Ross is necessary close to the soil surface to accurately model the cumulative infiltration. Li et al., [18] investigated the tideinduced seawater-groundwater circulation in shallow beach aquifers using a finite element model MARUN with a dimensionless formulation, with results consistent with existing results of field observations and numerical simulations.

Most of the models mentioned above are dependent on the pressure or water head. There is not a strictly definite interface between water and air in the seepage field because of the presence of capillary fringe in nature. Therefore, the seepage surface is not a strictly defined the geometrical surface but a transition region in which the degree of saturation changes rapidly [19].

This study presents a numerical model to simulate the unsteady seepage flow through earth dams. The numerical model was solved by the Z_SOIL program. Experiments of unsteady seepage flow through dam were conducted in laboratory. The reliability and the accuracy of the numerical model are verified by experimental data.

General layout of the earth dam overlaying the foundation soil is shown in figure (1).

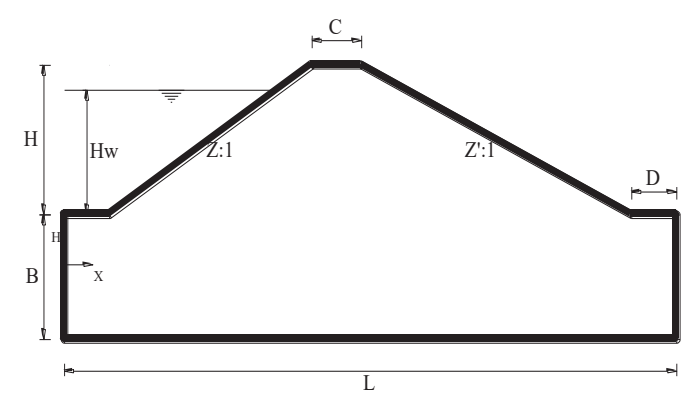

Figure (1): Problem Definition of Soil

\section{NUMERICAL MODEL}

Numerical Methods are used to solve nonlinear problems described by partial differential equations or linear flow problems with irregular boundaries. Finite Difference, Finite Element or Boundary Element Methods based on the replacement of partial differential 
equation, with a system of algebraic equations, which can be solved by direct or indirect Numerical Methods.

In the present study, The Finite Element Method is used to solve the problem of seepage flow through dams. The governing equation of seepage through the studied porous media is "unsteady (transient) saturated equation" its shape is:

$$
\begin{aligned}
\frac{\partial}{\partial x}\left(K_{x} \frac{\partial h}{\partial x}\right)+ & \frac{\partial}{\partial y}\left(K_{y} \frac{\partial h}{\partial y}\right) \\
& =S_{s} \frac{\partial h}{\partial t}
\end{aligned}
$$

Where $\mathrm{h}$ is the hydraulic head, $\mathrm{x} \& \mathrm{y}$ are the Cartesian coordinates, $\mathrm{K}_{\mathrm{x}}$ is hydraulic conductivity in $\mathrm{x}$ direction, $\mathrm{K}_{\mathrm{y}}$ is hydraulic conductivity in $\mathrm{y}$ direction, $\mathrm{S}_{\mathrm{s}}$ is specific storage and $\mathrm{t}$ is time.

By using the Z_SOIL program, we can apply this equation on the model (dam) to solve it. In the numerical solution we seek on a discrete approximation for the solution i.e., computed values of the field variable at a set of specified points within the model (dam) at a set of specified times.

Figure (2) represents Z-Soil version 5.79 main screen for solving soil, rock and structural mechanics in dry or saturated media based on Finite Element Method. Figure (3) shows Program working area and mesh generation using four node linear quadrilateral and seepage elements. The dam section used in the present paper has the dimensions that will be shown in figure (8). Figure (4) represents material properties assignment window for all types of elements used in the mesh.

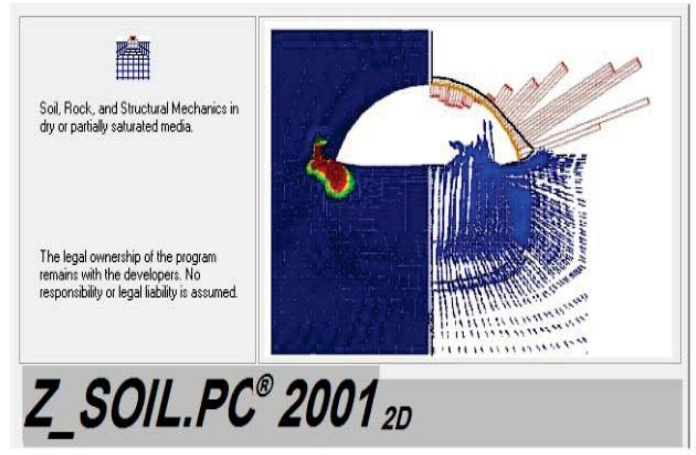

Figure 2: The Program Main Screen

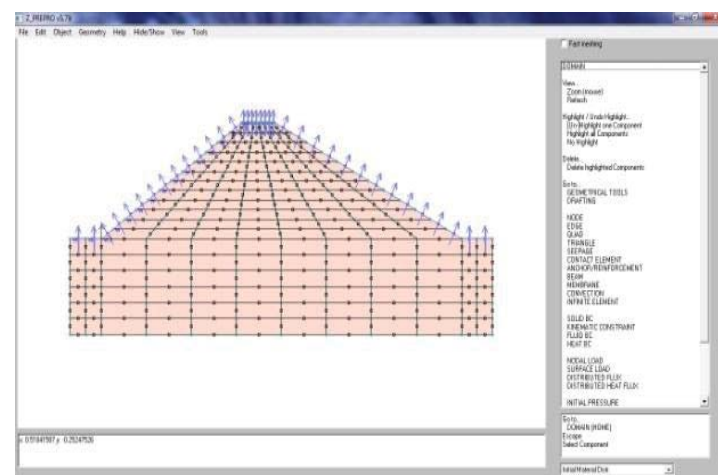

Figure (3): Program Working Area\& Mesh Generation

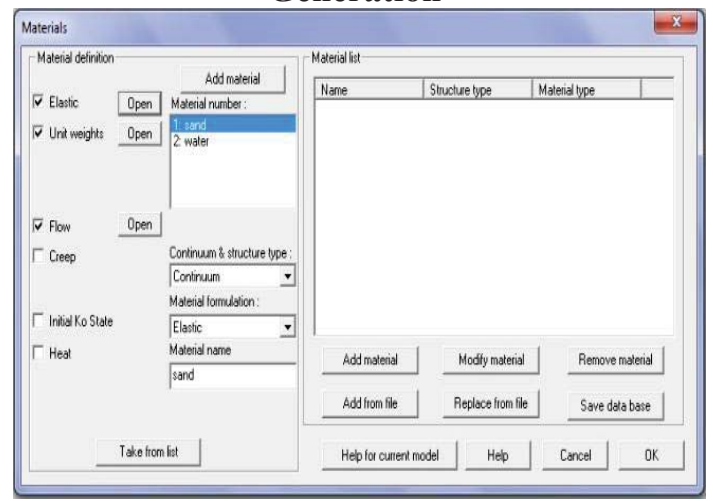

Figure (4): Material Properties Assignment

The case studied is a simplified representation of typical sand dam geometry. The properties of sand are assigned as follow:

Elastic modulus $(\mathrm{E})=10 \times 10^{4} \mathrm{MPa}$;

Poisson's ratio $(v)=0.3$;

Density of concrete $(\gamma)=18.0 \mathrm{kN} / \mathrm{m}^{3}$.

Figures (5), (6) and (7) show the outputs from the program. Porewater pressure and hydraulic head distributions could be presented in form of color map or contour lines. 


\section{A STUDY OF UNSTEADY FLOW THROUGH EARTH DAMS}

Mowafy, Salem, El-nikhily, Shaaban

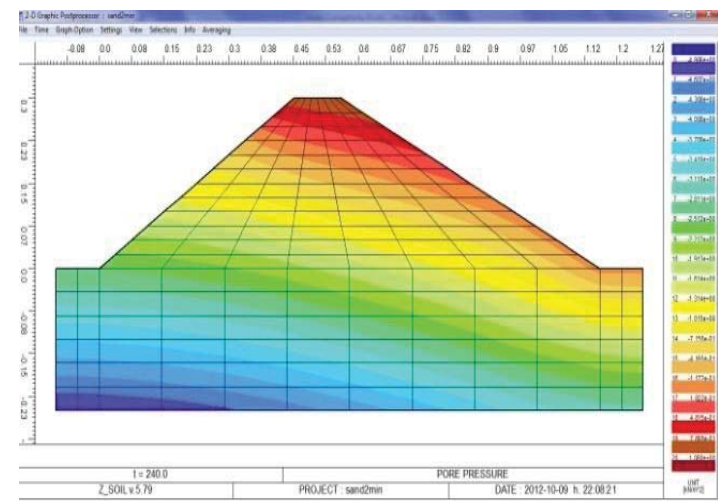

Figure (5): Pore Water Pressure

Distribution in Form of Color Map

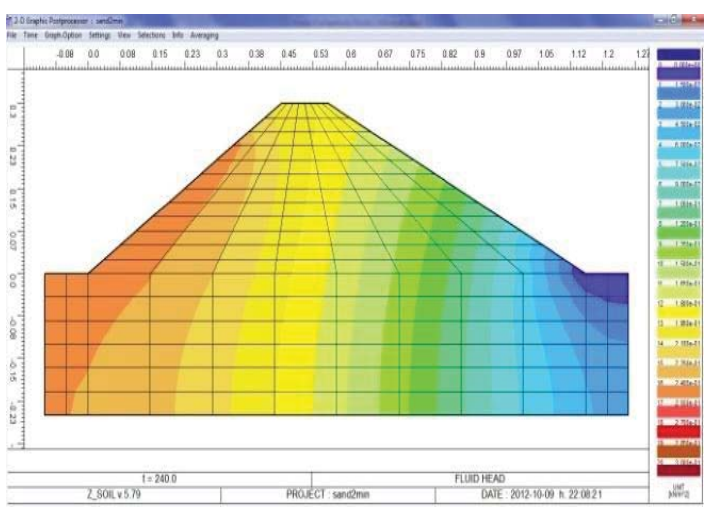

Figure (6): Hydraulic Head Distribution in Form of Color Map

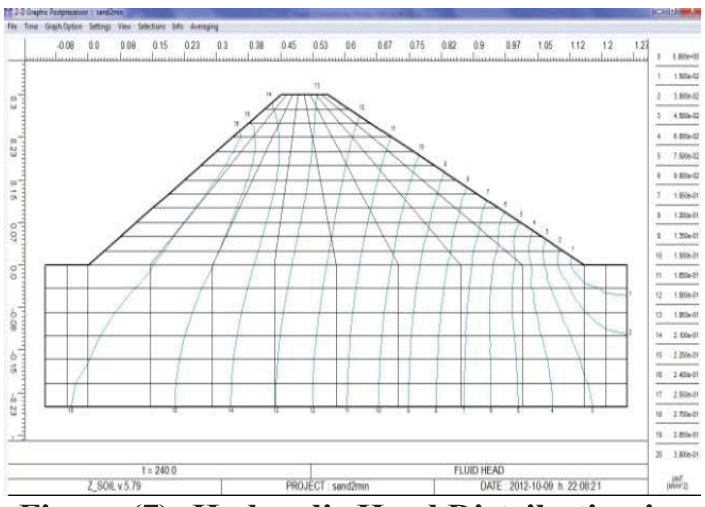

Figure (7): Hydraulic Head Distribution in Form of Contour lines

\section{EXPERIMENTAL MODEL}

In this section, the experimental model is used to examine the ability of the numerical model in simulating 2-D problems with complex boundary conditions.

The presented experimental work was carried out using the Permeability and
Seepage Model in the Hydraulics and Fluid Mechanics Laboratory, Faculty of Engineering, Zagazig University, Zagazig, Photo (1).The layout of the experimental facility and sizes are shown in figure (8).

As shown in figure (8), there is a steel bed supported on a steel frame. A modification to the model is made, where the steel bed had been perforated at 27 equally spaced points to connect piezometers for head measurement.

Leveling adjustments are provided in the base of the frame and are checked before initiating experiments. The transparent sides of the tank are supported and sealed by a glazing method providing minimum sight obstruction. One side of the tank is made of toughened glass, which was extremely strong and abrasion resistant and thus preserved its clarity indefinitely. The other side is made of clear Plexiglas, which permitted the insertion of pressure tapping as required. Each end of the tank is fitted with a steel cover plate. Adjustable overflows are provided to maintain the levels at either end of the tank constant. End plates incorporated a drain for maintenance and cleaning.

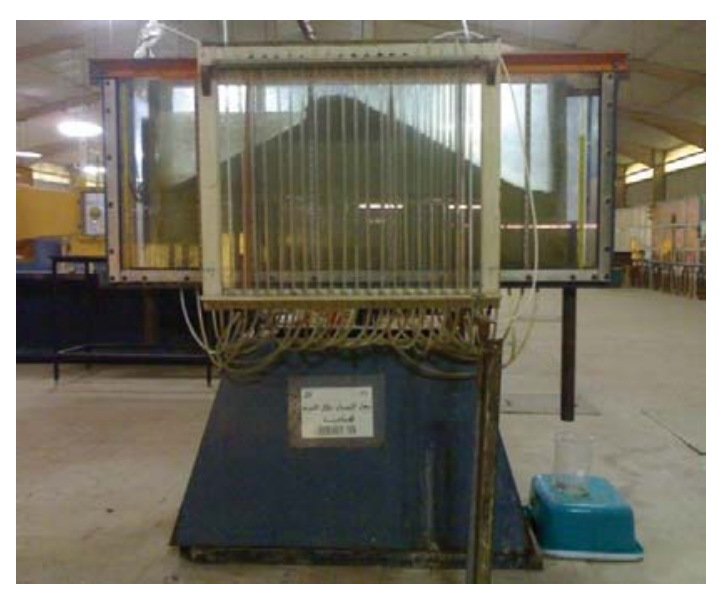

Photo (1) Alignment of the Seepage and Permeability Model 


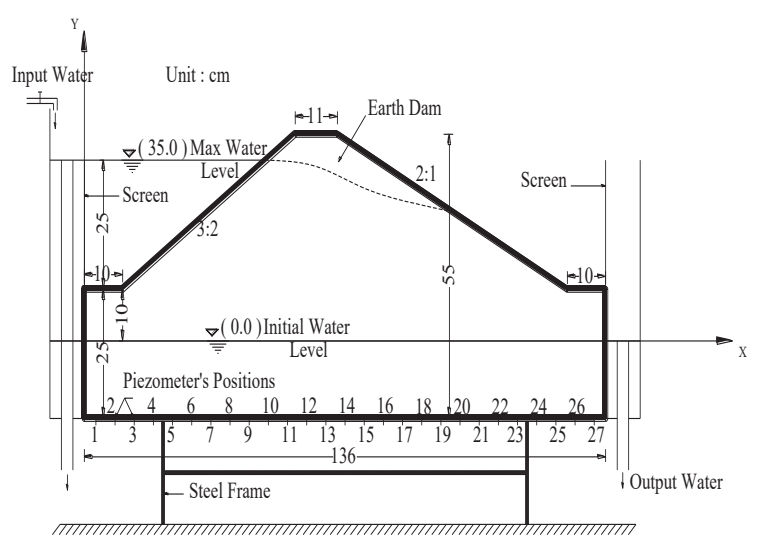

Figure (8): Layout of experimental facility

Two screens as shown in figure (8) are made from commercially available perforated metal sheets. The perforations should prevent the material used in the model from getting through. The screens are fixed in the model such that one after the adjustable upstream overflow and one before the adjustable downstream overflow. The screens are fixed to be rigid enough by bending their longitudinal edges as indicated. This prevented collapse under the pressure of the material used.

With respect to the materials used in the model, one soil type is used in the present research. The soil type used in the experimental work is sandy soil. The grain size distribution curve for the soil type is shown in figure (9). The void ratio is estimated to be 0.23 . The saturated hydraulic conductivity is determined in the steady-state flow case, with $\mathrm{K}=3.5 \times 10^{-4} \mathrm{~m} / \mathrm{s}$.

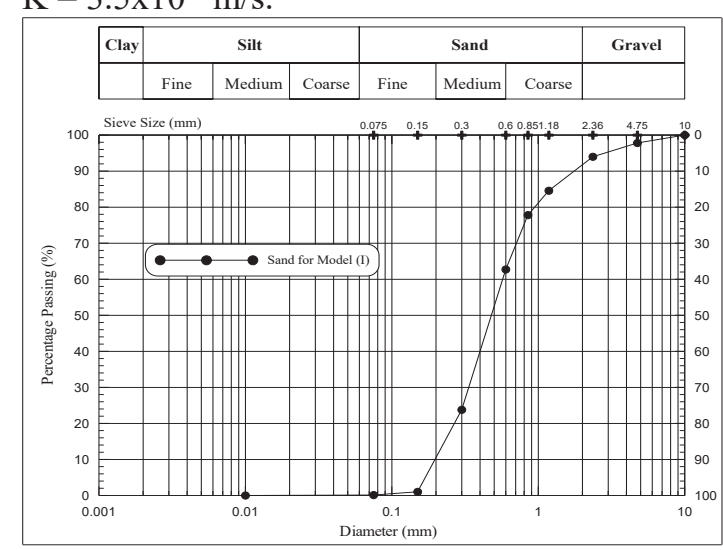

Figure (9): Grain Size Distribution Curve for the Sand Soil
The seepage surface position is obtained by observing the actual stream in the dam against the engraved coordinate grids on the observation window. The potassium permanganate solution is used as tracer.

As the initial state, the upstream of the dam is empty. The water level then rose from 0 to $0.35 \mathrm{~m}$ in $4.0 \mathrm{~h}$. The pressure at each piezometer point was recorded at intervals of $15 \mathrm{~min}$. each at the first hour and intervals of $30 \mathrm{~min}$. for the remaining 3 hours. The seepage surface position was recorded at the same time.

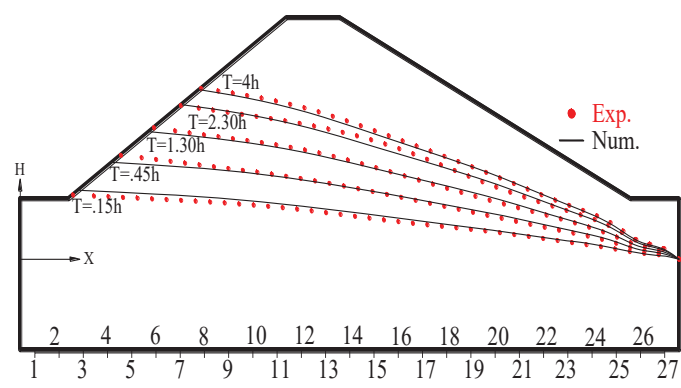

Figure (10): Comparisons of Seepage Surface between Numerical Solution and Experiment

The ability of the numerical model to simulate the water table affected by unsteady head boundary conditions was verified with the present experimental data. The comparisons of seepage surface between the numerical and experimental results are shown in figure (10). It can be seen that the numerical model can simulate the time evolution of seepage surface quite accurately.

The comparisons of pressure are shown in figure (11). The dam height " $\mathrm{H}=0.30 \mathrm{~m}$ " was used as a reference in the comparisons. It can be seen that the numerical solutions agree well with the experimental pressure courses. All of them show that the accuracy and the reliability of the model are adequate to deal with complex boundary conditions like unsteady head and seepage surface. 


\section{A STUDY OF UNSTEADY FLOW THROUGH EARTH DAMS}

Mowafy, Salem, El-nikhily, Shaaban

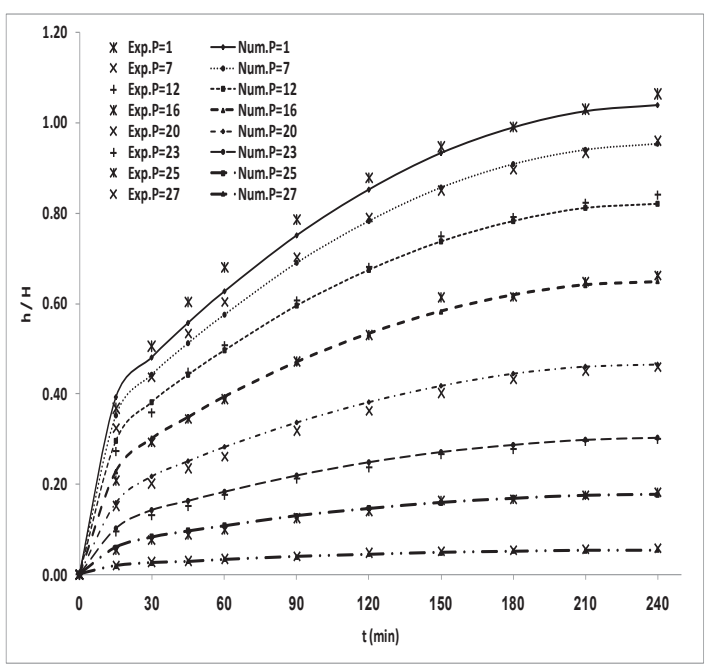

Figure (11): Comparisons of Heads at (8) Piezometers

\section{ANALYSIS AND DISCUSSIONS}

As shown in figure (11), there is a great agreement between the numerical results from Z_SOIL program and the experimental study. The program is reliable to deal with complex boundary conditions like unsteady head and seepage surface.

The investigation of the unsteady flow through the earth dam involves how to deal with seepage line through the dam? to improve its gradient. And to do that we can change some parameters affecting the gradient of the seepage line like crest width (C), base height (B), relative hydraulic conductivity $\left(\mathrm{k}_{\mathrm{x}} / \mathrm{k}_{\mathrm{y}}\right)$ for the base and the embankment then compare the results of head at every piezometer with the original case which mean $\mathrm{C}=12, \mathrm{~B}=24$, $\left(\mathrm{k}_{\mathrm{x}} / \mathrm{k}_{\mathrm{y}}\right)$ for base and embankment $=1$. For simplicity (10) piezometers are taken representing the (27) piezometers.

In the first, we change the crest width $(\mathrm{C})$ to be $12,9,6$, and 3 with constant of base height (B), relative hydraulic conductivity $\left(\mathrm{k}_{\mathrm{x}} / \mathrm{k}_{\mathrm{y}}\right)$ for the base and the embankment.

From figure (12), we note that the change in head decreases with the increase of time, the maximum change is founded at the upstream face at about $0.30 \%$. Along the dam, it is found that the change in head decreases and the minimum change founded at the last quarter of the dam so that the seepage lines converge and the change in head to time decrease until reaches zero.

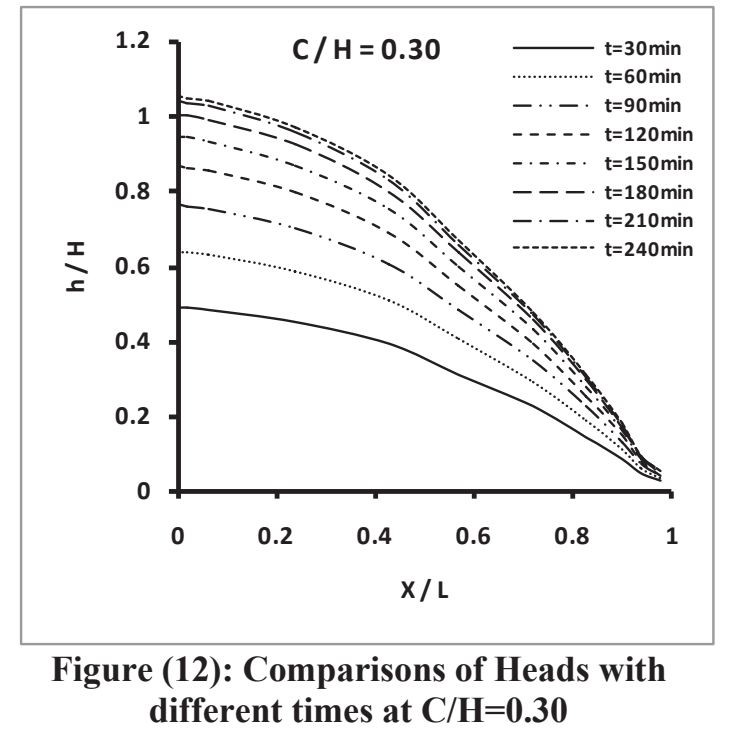

Figure (13) shows that the increase of the crest width decreases the head through the dam, as shown at the middle.

The base height (B) is considered 30, 24, and 15 with constant of crest width (C). The relative hydraulic conductivity $\left(\mathrm{k}_{\mathrm{x}} / \mathrm{k}_{\mathrm{y}}\right)$ for the base and the embankment as showed in the original case and observe the change of water head through the dam with respect to dam length and time.

From figure (14), it is noted that the change in head decreases with the increase of the time. The maximum change founded at the upstream face and equal to $0.33 \%$. Along the dam base it is found that the head decreases and the minimum change is founded at the last quarter of the dam so that the seepage lines converge and the change in head to time decrease until reaches zero. 


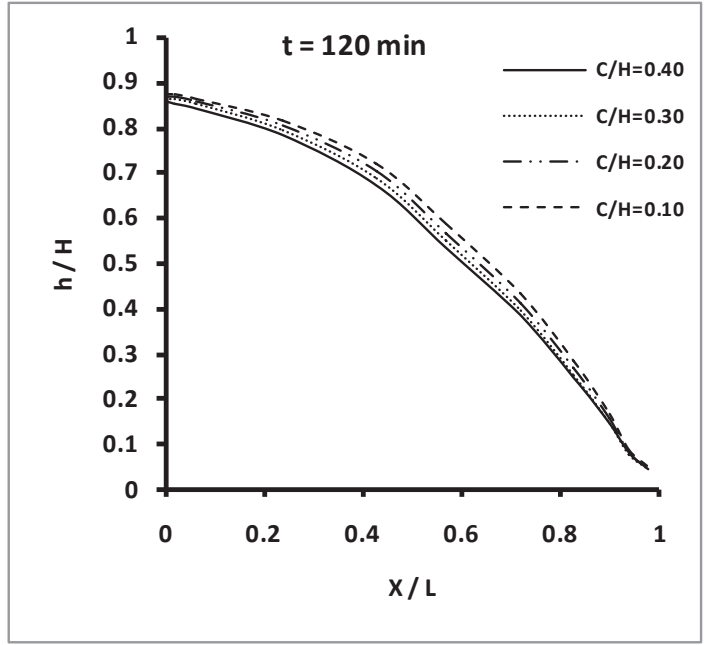

Figure (13): Comparisons of Heads with different $\mathrm{C}$ at $\mathrm{t}=120 \mathrm{~min}$.

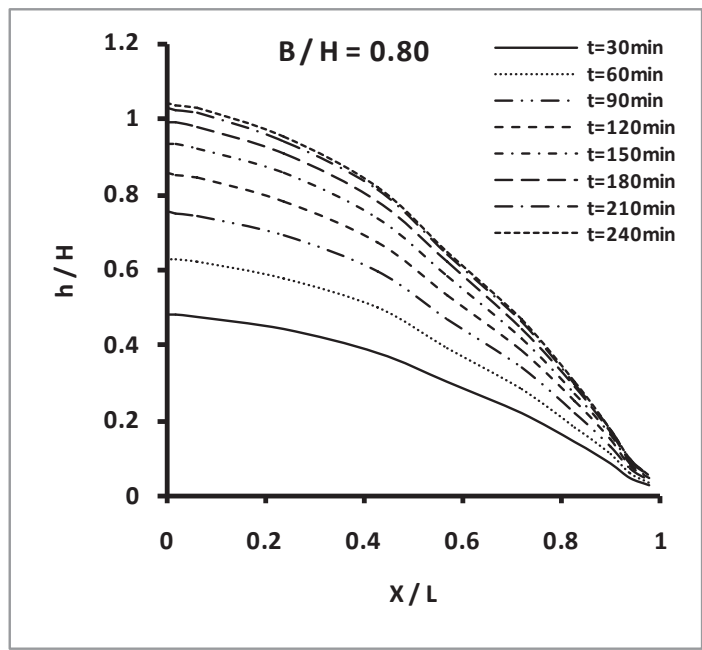

Figure (14): Comparisons of Heads with different times at $\mathrm{B} / \mathrm{H}=\mathbf{0 . 8 0}$

Figure (15) shows that the increase of the base height decreases the head through the dam, as shown at the upstream face. And the reversal at the middle may be attributed to the increase of the domain area or seepage line change.

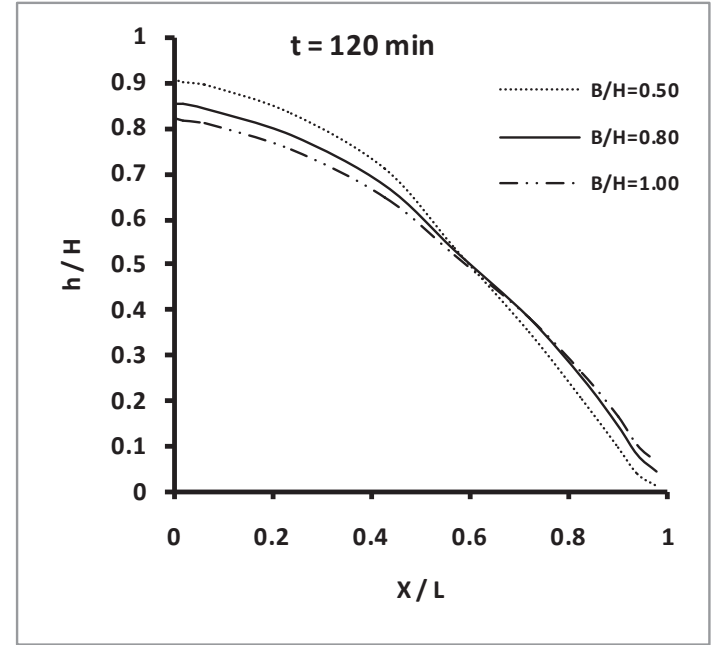

\section{Figure (15): Comparisons of Heads with} different $B$ at $t=120 \mathrm{~min}$.

The relative hydraulic conductivity of base $\left(\mathrm{k}_{\mathrm{x}} / \mathrm{k}_{\mathrm{y}}\right)$ is changed to be $1,2,4,6,8,10$ with constant of crest width (C), base height (B) and relative hydraulic conductivity of embankment $\left(\mathrm{k}_{\mathrm{x}} / \mathrm{k}_{\mathrm{y}}\right)$, as shown in the original case, and observe the change of water head through the dam with respect to dam length and time.

From figures (16 and 17), it is noted that the change in head decreases with the increase in the time. The maximum change is founded at upstream face with about $0.31 \%$ along the dam. It is found also that the change in head decrease and the minimum change founded at the last quarter of the dam so that the seepage lines converge.

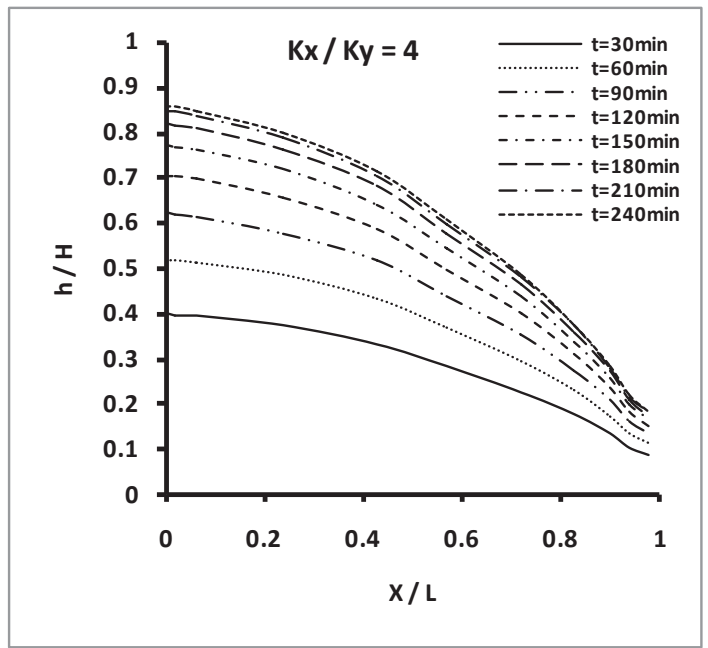

Figure (16): Comparisons of Heads with different times at $\mathrm{k}_{\mathrm{x}} / \mathrm{k}_{\mathrm{y}}=4$ 


\section{A STUDY OF UNSTEADY FLOW THROUGH EARTH DAMS}

Mowafy, Salem, El-nikhily, Shaaban

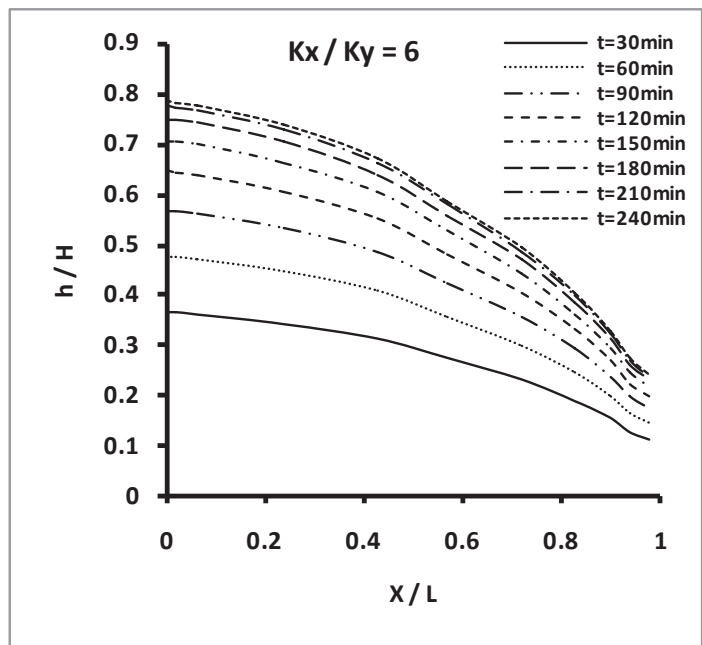

Figure (17): Comparisons of Heads with different times at $\mathbf{k}_{\mathrm{x}} / \mathrm{k}_{\mathrm{y}}=6$

Figure (18) shows that the increase of the relative hydraulic conductivity of base decreases the head through the dam, as shown at the upstream face. The reverse occurred at the last quarter may be attributed to the increase of the domain area.

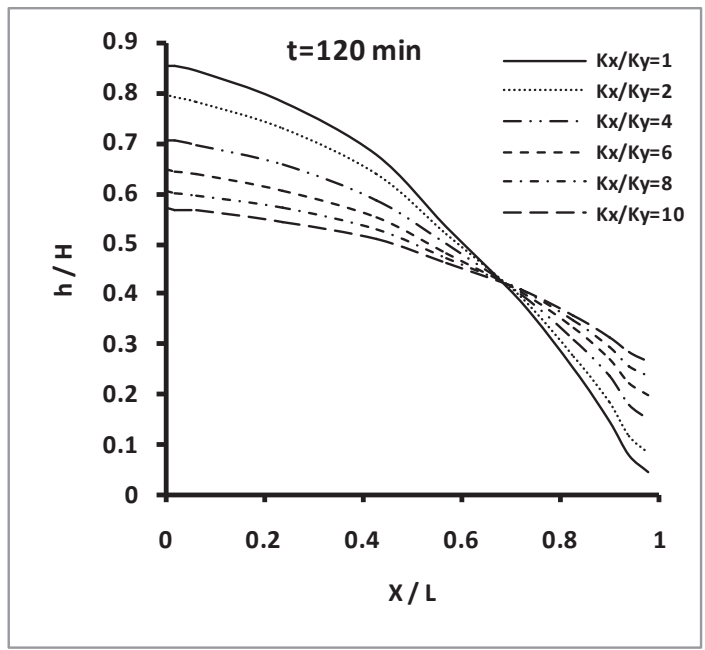

Figure (18): Comparisons of Heads with different $k_{x} / k_{y}$ at $t=120$ min.

The relative hydraulic conductivity of embankment $\left(\mathrm{k}_{\mathrm{x}} / \mathrm{k}_{\mathrm{y}}\right)$ is changed to be $1,2,4$, $6,8,10$ with constant of crest width (C), base height (B) and relative hydraulic conductivity of base $\left(\mathrm{k}_{\mathrm{x}} / \mathrm{k}_{\mathrm{y}}\right)$ as shown in the original case and observe the change of water head through the dam with respect to dam length and time.

From figures (19 and 20), it is noted that the change in head decreases as the time increases. The maximum change is founded at the upstream face of the dam at about $0.32 \%$. Along the dam base, it is founded that the change in head decreases and the minimum change founded at the last quarter of the dam so that the seepage lines converge and the change in head to time decrease until reaches zero.

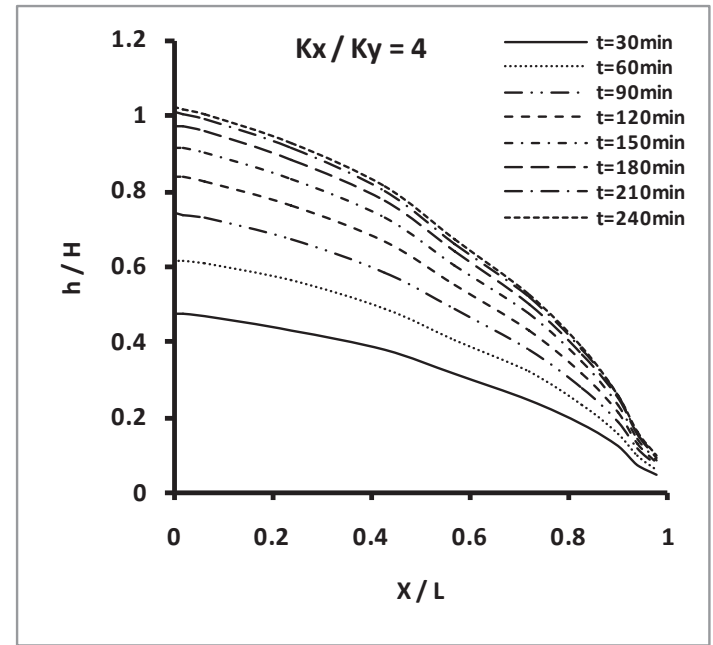

Figure (19): Comparisons of Heads with different times at $k_{x} / k_{y}=4$

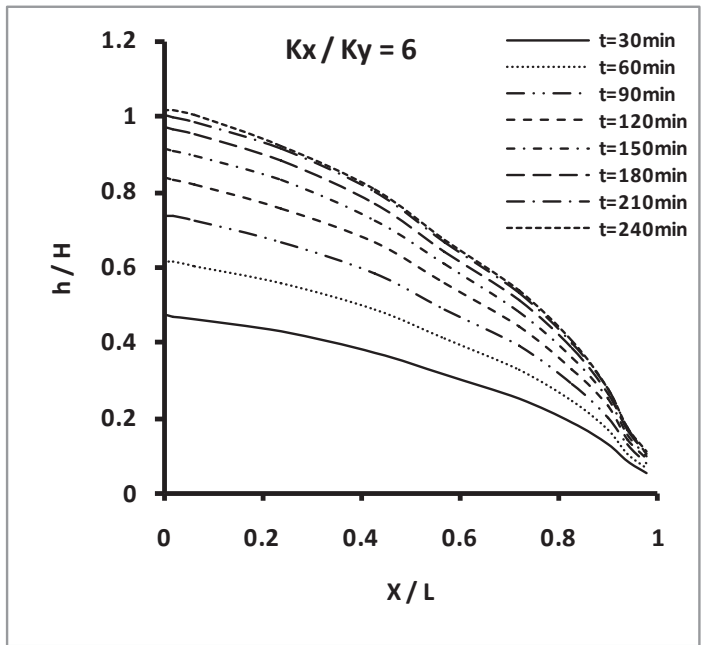

Figure (20): Comparisons of Heads with different times at $k_{x} / k_{y}=6$

Figure (21) shows that the increase in the relative hydraulic conductivity of embankment 
decreases the head through the dam, as shown at the upstream face. The reverse near dam middle may be attributed to the increase of the domain area.

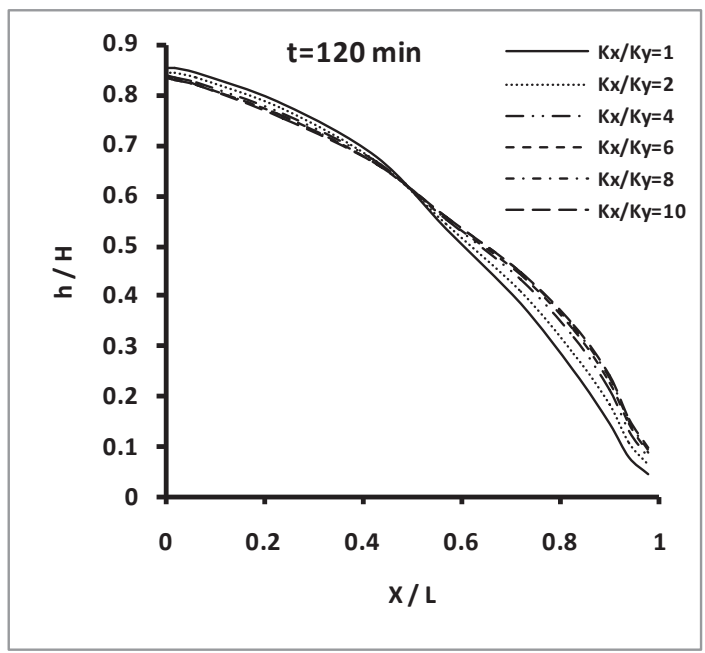

Figure (21): Comparisons of Heads with different $k_{x} / k_{y}$ at $t=120$ min.

\section{CONCLUSIONS}

Using saturation and water head as variables, Z_Soil commercial model is used to simulate unsteady seepage flow through an earth dam. Comparisons between the numerical solutions and the experimental results show that the model can simulate the variations of seepage surface with the time quite accurately. This shows that the method of determining the seepage surface through the saturation description is natural, logical and practical in actual applications.

It is concluded that with both saturation and water head as variables in one model, the capture of seepage surface is made simple and easy. The model can describe the distribution of saturation and water head directly. The examples show the accuracy and reliability of the numerical model in simulating unsteady seepage flow with complex conditions.

From the previous analysis of the results, the following conclusions are obtained:

1- The increase of the crest width decreases the head through the dam. The change in head through the sandy dam decreases as time increases. The maximum change is founded at the upstream face of the dam is about $0.30 \%$.
2- The increase of the base height decreases the head through the dam. The change in head through the sandy dam decreases with the increase of the time. The maximum change founded at the upstream face of dam at about $0.33 \%$

3- The increase in the relative hydraulic conductivity of base decreases the head through the dam. The change in head through the sandy dam decreases as the time increases. The maximum change is founded at the upstream face with about $0.31 \%$.

4- The increase in the relative hydraulic conductivity of embankment decreases the head through the dam. The change in head through the sandy dam decreases as the time increases. The maximum change is founded at the upstream face at about $0.32 \%$.

\section{REFERENCES}

1- Peng, H., and Chen, S., (2002), "Finite element analyses of unstable seepage in saturated-unsaturated rock", Journal of Hydrodynamics, Vol.17, No.2, PP.253-259.

2- Zhang, X.H., Zhang, X.W., and Wang, H., (2007), "Coupled simulation the effect of tailings stacks on groundwater and groundwater quality", Journal of Hydrodynamics, Vol.22, No.5, PP.654-664.

3- Ataie, A.B., Volker, R.E., and Lockington, D.A., (1999), "Tidal effects on seawater intrusion in unconfined aquifers", Journal of Hydrology, Vol.216, No.1-2, PP.17-31.

4- Hou, J., Zhang, S.K., and DU, Q.J., (2008), "A streamline-based predictive model for enhanced oil-recovery potentiality", Journal of Hydrodynamics, Vol.20, No.3, PP.314-322.

5- Chen, S.H., Wang, W.M., and She, C., (2000), "Unconfined seepage analysis of discontinuous rock slope", Journal of Hydrodynamics, Vol.12, No.3, PP.75-86.

6- Adil, E., Shu, L.C., and Hao, Z.C., (2004), "Numerical simulation of groundwater dynamics for Songhuajiang 


\section{A STUDY OF UNSTEADY FLOW THROUGH EARTH DAMS}

Mowafy, Salem, El-nikhily, Shaaban

River valley in China," Journal of Hydrodynamics, Vol.16, No.3, PP.332-335.

7- Zhou, Z.F., and G, G.X., (2005), "Numerical modeling for positive and inverse problem of 3D seepage in double fractured media", Journal of Hydrodynamics, Vol.17, No.2, PP.186-193.

8- Ge, J.H., Li, G.X., and Jie, Y.X., (2003), "Application of element-free method to the seepage calculation with free surface", Journal of Computational Mechanics, Vol.20, No.2, PP.241-243.

9- Chen, C.L., Pan, W.Y., and Wang, X., (2005), "Variable element seepage coefficient method for seepage numerical analysis with free surface", Geotechnical Engineering Technique, Vol.19, No.4, PP.166-169.

10-Zhang, Q.F., and Wang, Y.M., (2005), "Research on improved cut-off negative pressure method for unsteady seepage flow with free surface", Journal of Hydrodynamics, Vol.17, No.5, PP.521531.

11- Hua, L.N., and Yu, X.P., (2009), "An enhanced element-free Galerkin method for dynamic response of poroelastic seabed", Journal of Hydrodynamics, Vol.21, No.3, PP.429-435.

12-Sun, D.M., Zhu, Y.M. and Zhang, M.J., (2007), "Water-air two-phase flow model for numerical analysis of rainfall infiltration", Journal of Hydraulic Engineering, Vol.38, No.2, PP.150-156.

13- Sun, D.M., Zhu, Y.M. and Zhang, M.J., (2007), "Unsteady seepage problems due to water level fluctuation", Journal of Tianjin University, Vol.40, No.7, PP.779785.

14- Lockington, D.A., (1997),"Response of unconfined aquifer to sudden change in boundary head". Journal of Irrigation and Drainage Engineering, Vol.123, No.1, PP.24-27.
15- Ataie, A.B., Volker, R.E., and Lockington, D.A., (1999), "Numerical and experimental study of seepage in unconfined aquifers with a periodic boundary condition", Journal of Hydrology, Vol.222, No.1-4, PP.165-184.

16- Ross, P.J., (2003), "Modeling soil water and solute transport-fast, simplified numerical solutions", Agron. J., Vol.95, No.6, PP.1352-1361.

17- Varado, N., Braud, I., and Ross, P.J., (2006), "Assessment of an efficient numerical solution of the 1D Richards equation on bare soil", Journal of Hydrology, Vol.323, No.1-4, PP.244-257.

18-Li, H.L., Michel, C.B., and James, W.W., (2008), "Tide-induced seawatergroundwater circulation in shallow beach aquifers", Journal of Hydrology, Vol.352, No.1-2, PP.211-224.

19- Jin, S., Geng, Y.F., and Wang, Z.L., (2004), "Computation of seepage flow of dam's free surface by using saturatedunsaturated model", Journal of Dalian University of Technology, Vol.44, No.1, PP.110-113.

20- Tuli, A., and Hopmans, J.W., (2004), "Effect of degree of fluid saturation on transport coefficients in disturbed soils", European Journal of Soil Science, Vol.55, No.1, PP.147-164.

21- Peter, L., Fritz, S., and Christoph, H., (1998), "Effect of hysteresis on water flow in a sand column with a fluctuating capillary fringe", Journal of Contaminant Hydrology, Vol.33, No.1-2, PP.81-100.

22- Kevin, D.P., and Ian, R.F., (2006), "Evaluation of a Geosynthetic capillary barrier", Geotextiles and Geomembranes, Vol.24, No.1, PP.64-71.

23-Mualem, Y., (1976), "A new model for predicting the hydraulic conductivity of unsaturated porous media", Water Resources Research, Vol.12, No.3, PP.513-522. 
The Egyptian Int. J. of Eng. Sci. and Technology

Vol. 17, No. 1 (Jan. 2014)

24- Vangenuchten, M.T., (1980), "A closedform equation for predicting the hydraulic conductivity of unsaturated soils", Soil Science Society of America Journal, Vol.44, No.5, PP.892-898.

25- Beaugendre, H., and Ern, A., (2006), "A seepage face model for the interaction of shallow water tables with the ground surface: Application of the obstacle-type method", Journal of Hydrology, Vol.329, No.1-2, PP. 258-273.

26- Bathe, K.J., (1986), "Finite element method in engineering analysis", New York: McGraw-Hill. 